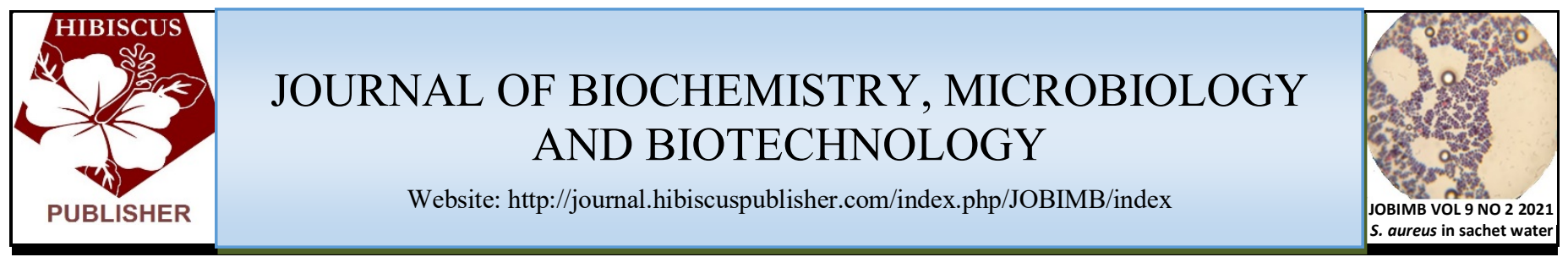

\title{
Mathematical Modelling of the Growth of Bacillus cereus Strain wwcp1on Malachite Green Dye
}

\author{
Salihu Yahuza ${ }^{1}$ and Ibrahim Alhaji $\mathrm{Sabo}^{2 *}$ \\ ${ }^{1}$ Department of Microbiology and Biotechnology, Faculty of Science, Federal University Dutse, \\ PMB 7156, Dutse, Jigawa State, Nigeria. \\ ${ }^{2}$ Department of Microbiology, Faculty of Pure and Applied Sciences, Federal University Wukari, PMB 1020, \\ Wukari, Taraba State, Nigeria.
}

\author{
*Corresponding author: \\ Alhaji Sabo, \\ Department of Microbiology, \\ Faculty of Pure and Applied Sciences, \\ Federal University Wukari, PMB 1020, \\ Wukari, Taraba State, \\ Nigeria. \\ Email: ibrahimsabodzk@gmail.com
}

\begin{tabular}{l}
\hline HISTORY \\
Received: $12^{\text {th }}$ Oct 2021 \\
Received in revised form: $15^{\text {th }}$ Dec 2021 \\
Accepted: $20^{\text {th }}$ Dec 2021 \\
\hline KEYWORDS \\
Bacilus cereus \\
Malachite green dye \\
Mathematical modelling \\
Growth \\
Von Bertalanffy
\end{tabular}

\section{INTRODUCTION}

A common biocide in the aquaculture industry is malachite green (MG), which is one of the most widely used (MG). One of the most effective anti-protozoal and anti-fungal drugs now available on the market. It has been used to manage skin and gill flukes as a general ectoparasiticide, as well as other parasites. Despite the fact that MG has long been used extensively as a topical therapeutic, aquaculture enterprises have largely neglected the possibility that topically applied therapeutants could have major internal impacts on their products. It is also employed as a food colouring agent and as an ingredient in foods, as a medical disinfectant and antihelminthic, and as a dye in the textile industry, among other things (such as silk and wool). Because of the dangers it causes to those who consume seafood that has been treated with MG, this material has become extremely contentious [1-4]. MG is produced by condensing benzaldehyde with two parts of diemethylaniline in the presence of strong sulfuric acid or zinc chloride to form a dark green crystalline solid known as MG. It is also possible to obtain MG in a 50/50 solution of acetate and hydrochloride salts, in addition to the salts of oxalate or hydrochloride. MG hydrochloride is manufactured by adding zinc chloride to the mixture and allowing it to precipitate, resulting in the development of a double zinc salt. In addition to the dye salt, a triphenylemethane dye can exist in two more ionic forms: the carbinol or pseudobase. They may enter cells as the pseudobase due to their high lipid solubility and ability to dissolve in lipids MG is reduced to its colourless form, leucoMG, in animals, which is then retained in their tissues as a result of biotransformation. The dye's precursor, leucoMG, has a structural resemblance to classic aromatic amines, and it is possible that it is present in the dye as a contaminant in the commercially manufactured dye. A number of researchers have estimated the $\mathrm{LC}_{50}$ values of different commercial dyes in fish at various time points over the course of several studies.

There are numerous variables that influence the toxicity of certain toxicants, such as the temperature, $\mathrm{pH}$, and hardness of the test water, making it difficult to analyse the effects on diverse species of fish [5-9]. The question of whether MG is teratogenic to fish has been investigated in great detail. Many other research, both clinical and experimental, have been conducted on MG over the years. Its toxicity to diverse organisms, aquatic and terrestrial has been reported [5,7-15] and its removal is thus warranted. Biodegradation of MG has been touted as an important aspect of MG bioremediation. The degradation and mineralization of MG by microorganisms has been reported. Bacterial growth and degradation of MG has been studied and show promising results for its potential use for the remediation of $\mathrm{MG}$ from the environment [16-28]. 
Bacterial growth curves typically followed a sigmoidal pattern, beginning with the lag section just after $t=0$, followed by the logarithmic section, then the bacteria reach the stationary phase, and finally enter the death phase. Various sigmoidal functions such as Huang, Baranyi-Roberts, Von Bertalanffy, Modified Gompertz, Modified-Logistics, Modified-Richards, Morgan-Mercer-Flodin and Buchnam-3-phase were statistically compared in order to describe the bacterial growth curve [29-33]. The $\mathrm{F}$ and $\mathrm{t}$ tests were used. The F test compares the lack of fit of the models to the measuring error. While in the $t$ test, confidence intervals for parameters can be estimated and used to differentiate between models. Also, the models were compared in relation to their ease of use.

All sigmoidal functions were modified to include all biologically significant parameters. The maximum specific growth rate ( $\mu$ max), the lag period, and the asymptotic values are important growth curve parameters. The maximum growth rate ( $\mu$ max) value can be used in the development of secondary models to investigate the effects of substrate, temperature, $\mathrm{pH}$, and product on growth rate. Most models of bacterial growth, fall somewhere between mechanistic and empirical properties, though these two groups can coexist in reality [33-36]. The use of primary models in the modeling of Bacillus cereus wwcp1 growth curve on malachite green dye is presented for the first time in this finding. This study is aimed at evaluating various available mathematical models such as Logistic, Gompertz, Von Bertalanffy, Buchanan three-phase, and, more recently, the Huang model in fitting and analyzing Bacillus cereus growth on malachite green dye.

\section{MATERIALS AND METHODS}

\section{Data Acquisition}

The graphical data from a published work by Wanyonyi et al [37] from Fig 5 (effect of temperature on the decolorization of MG dye) was processed using the software Webplotdigitizer 2.5, which digitizes the scanned figure and has been used and recognized by many researchers due to its precision and reliability [38]

\section{Statistical Analysis}

As previously, the adjusted coefficient of determination $\left(R^{2}\right)$, accuracy factor (AF), bias factor (BF), Root-Mean-Square Error (RMSE), and corrected AICc (Akaike Information Criterion) were used to calculate the statistically significant difference between the models [29,39-42].

\section{Fitting of the Data}

CurveExpert Professional software (Version 1.6) was used to fit the bacterial growth curve using multiple growth models (Table 1) through nonlinear regression with the Marquardt algorithm. The steepest ascent rifle of the curve was used to estimate the highest growth rate ( $\mu$ max), while the line crossing the $\mathrm{X}$-axis was used to estimate the lag time $(\lambda)$. For the modeling exercise, the highest growth rate was chosen
Table 1. Growth models used in this study.

\begin{tabular}{llc}
\hline \multicolumn{1}{c}{ Model } & $\mathrm{P}$ & Equation \\
$\begin{array}{l}\text { Modified } \\
\text { Logistic }\end{array}$ & 3 & $y=\frac{A}{\left\{1+\exp \left[\frac{4 \mu_{m}}{A}(\lambda-t)+2\right]\right\}}$ \\
$\begin{array}{l}\text { Modified- } \\
\text { Gompertz }\end{array}$ & 3 & $y=A \exp \left\{-\exp \left[\frac{\mu_{m} e}{A}(\lambda-t)+1\right]\right\}$ \\
$\begin{array}{l}\text { Modified- } \\
\text { Richards }\end{array}$ & 4 & $y=A\left\{1+v \exp (1+v) \exp \left[\frac{\mu_{m}}{A}(1+v)\left(1+\frac{1}{v}\right)(\lambda-t\right.\right.$
\end{tabular}

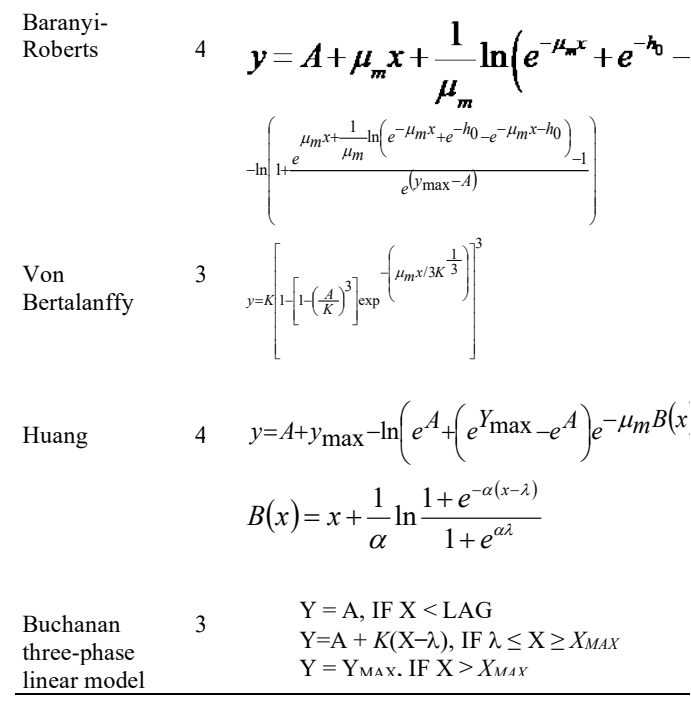

Note:

$\mathrm{A}=$ Bacterial growth lower asymptote;

$A=$ Bacterial growth lower asymptote;
$\mu_{\max }=$ maximum specific bacterial growth rate

$\mu_{\max }=$ maximum specific bacterial growth rate;
$\mathrm{v}=$ affects near which asymptote maximum growth occurs.

$\mathrm{v}=$ affects $\mathrm{n}$
$\lambda=$ lag time

$\mathrm{y}_{\max }=$ Bacterial growth upper asymptote;

$\mathrm{e}=$ exponent $(2.718281828)$

$\mathrm{t}=$ sampling time

$\alpha, \beta, \mathrm{k}=$ curve fitting parameter

$\mathrm{h}_{0}=$ a dimensionless parameter that quantifies the initial physiological state of the reduction process. The lag time $\left(\mathrm{h}^{-1}\right)$ can be calculated as $\mathrm{h}_{0}=\mu_{\max }$

\section{RESULTS AND DISCUSSION}

Based on bacterial growth modeling, the best model was discovered to be the von Bertalanffy model, which had the lowest RMSE, AICc, and adjusted $\mathrm{R}^{2}$ values. The AF and BF values for the model were also outstanding, with values close to 1.0. All of the model fitted to the date with the exception of the Buchanan-3phase, which show the worst fitting (Figs. 2 to 8). Table 3 shows the coefficients for the Von Bertalanffy model. 


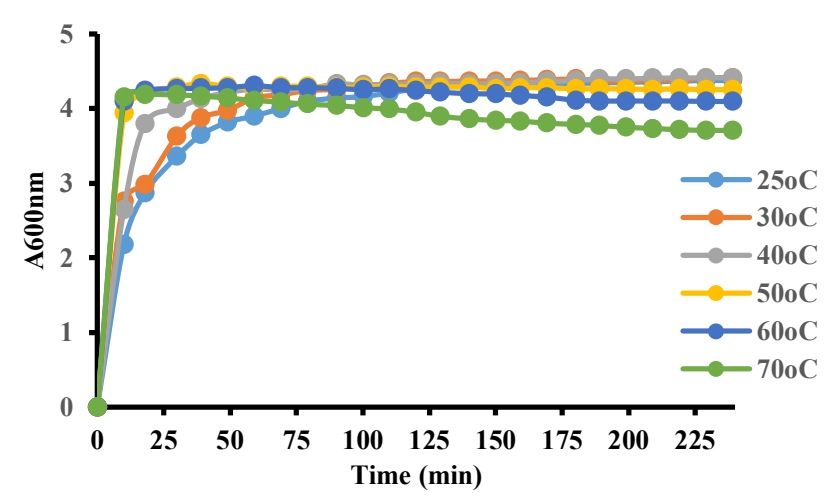

Fig. 1. Growth of Bacillus cereus on malachite green at different temperatures.

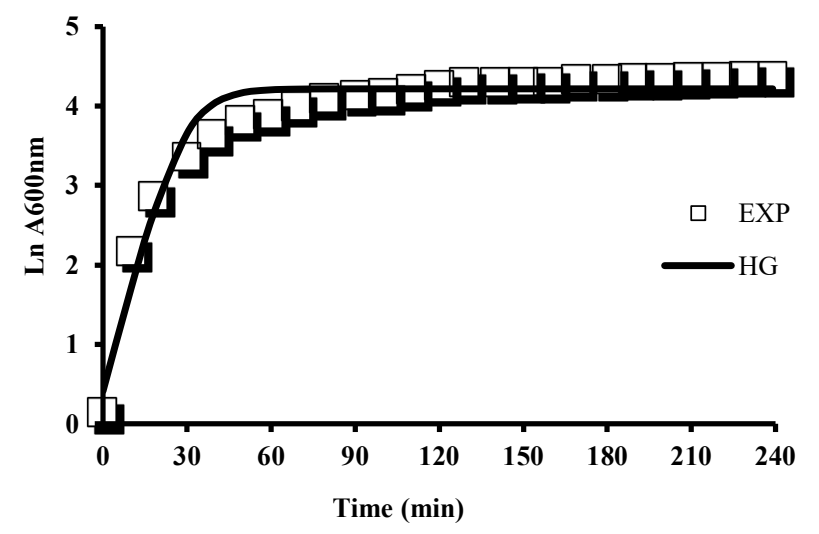

Fig. 2. Growth of Bacillus cereus modelled using Huang model.

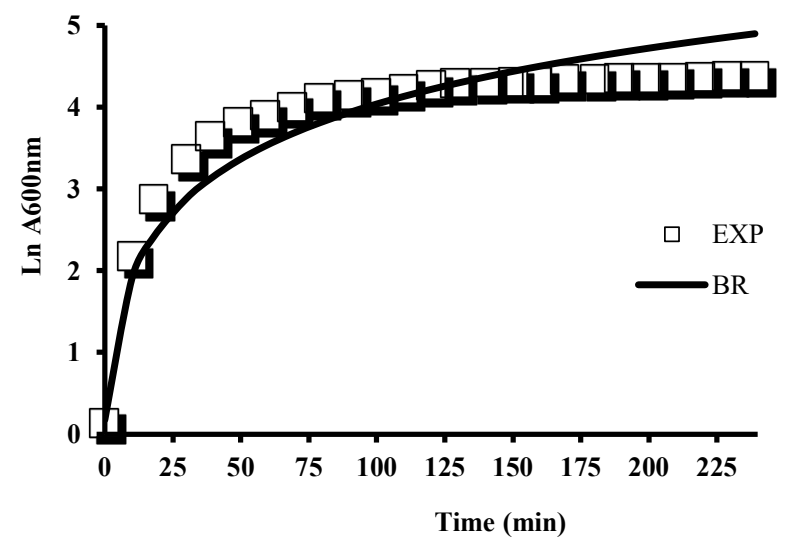

Fig. 3. Growth of Bacillus cereus modelled using Baranyi-Roberts model.

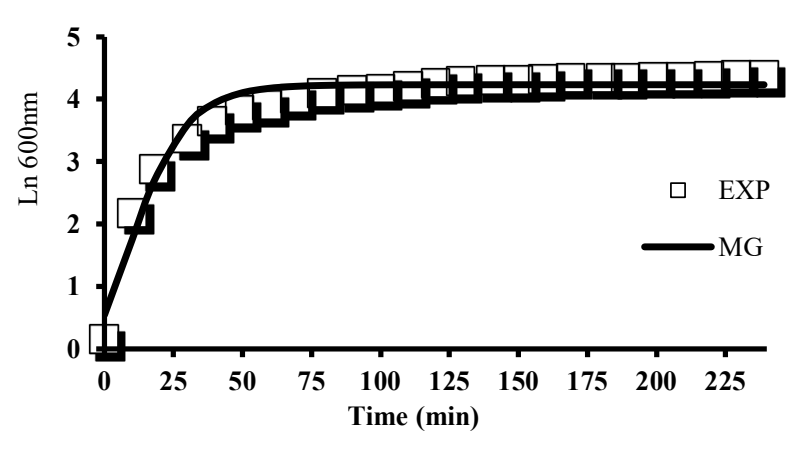

Fig 4. Growth of Bacillus cereus modelled using modified-Gompertz model.

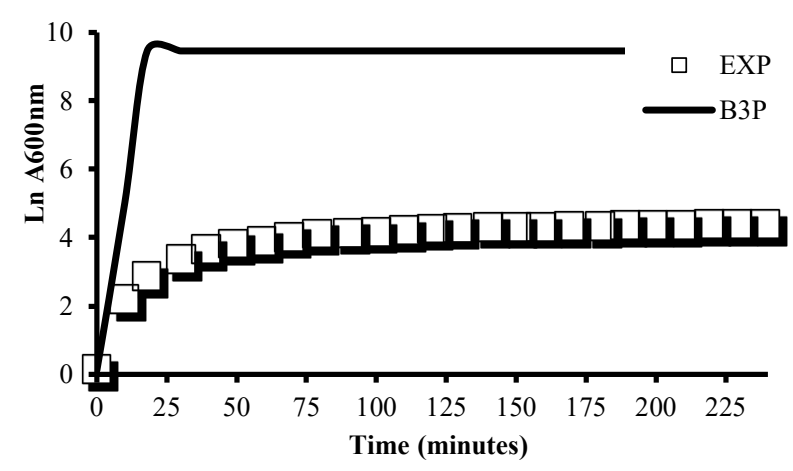

Fig. 5. Growth of Bacillus cereus modelled using Buchanan-3-phase model.

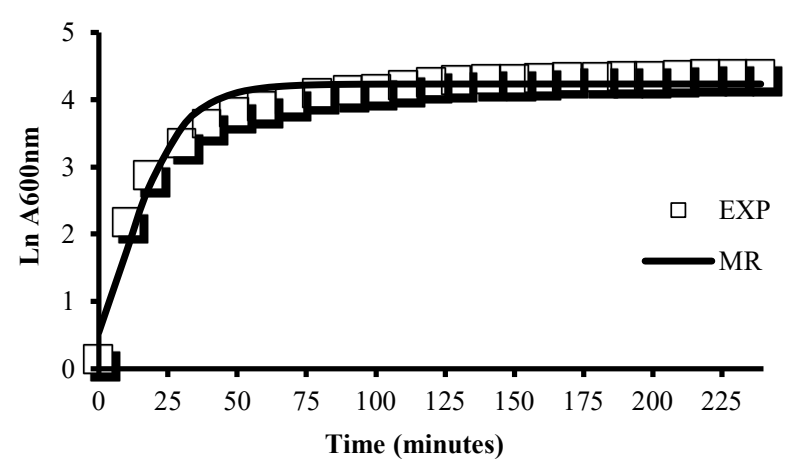

Fig. 6. Growth of Bacillus cereus modelled using modified-Richards model. 


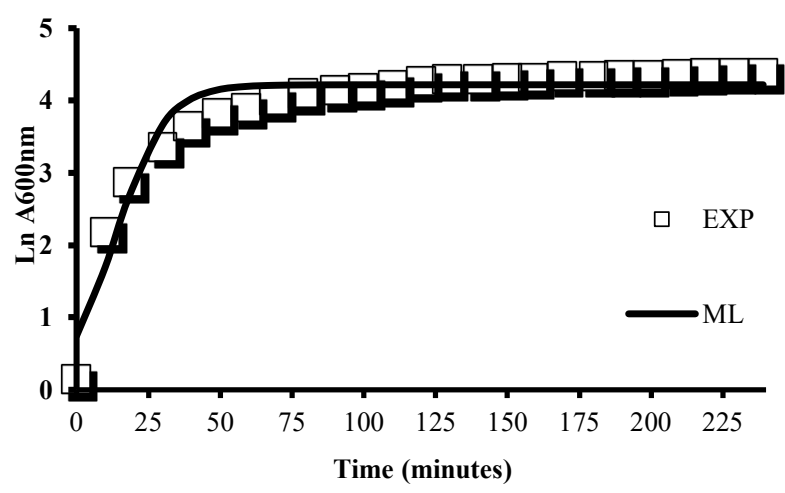

Fig. 7. Growth of Bacillus cereus modelled using the modified-Logistics model.

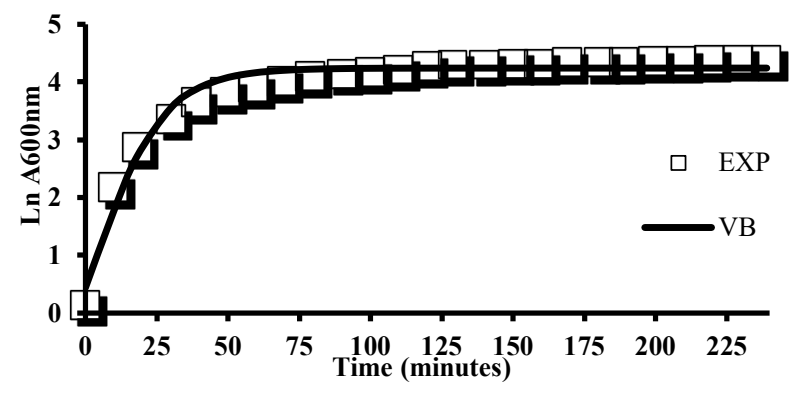

Fig. 8. Growth of Bacillus cereus modelled using the von Bertalanffy model.

Table 2. Statistical tests for the different models used to model the Bacillus cereus growth curve on malachite green dye.

\begin{tabular}{|c|c|c|c|c|c|c|}
\hline Model & $\mathrm{p}$ & RMSE & adR2 & $\mathrm{AF}$ & $\mathrm{BF}$ & $\mathrm{AICc}$ \\
\hline Huang & 4 & 0.2227 & 0.9393 & 1.0925 & 1.0349 & -58.30 \\
\hline Baranyi-Roberts & 4 & 0.3571 & 0.8892 & 1.0881 & 0.9957 & -34.69 \\
\hline Modified Gompertz & 3 & 0.1989 & 0.949 & 2.25 & 1.0482 & -67.93 \\
\hline Buchanan-3-phase & 3 & 5.5173 & -0.045 & 2.25 & 2.2224 & 98.199 \\
\hline Modified Richards & 4 & 0.2036 & 0.9465 & 1.0981 & 1.0482 & -62.78 \\
\hline Modified Logistics & 3 & 0.244 & 0.918 & 1.118 & 1.06 & -57.642 \\
\hline Von Bertalanffy & 3 & 0.178 & 0.961 & 1.09 & 1.04 & -73.591 \\
\hline
\end{tabular}

Table 3. Growth coefficients modelled using the von Bertalanffy model.

\begin{tabular}{lll}
\hline Parameters & Value & $95 \%$ Confidence interval \\
\hline $\mathrm{u}$ & 0.287 & 0.244 to 0.329 \\
$\mathrm{~A}$ & 2.757 & 2.131 to 3.382 \\
$\mathrm{k}$ & 4.323 & 4.285 to 4.362
\end{tabular}

The von Bertalanffy parameters such as $A$ (lower asymptote bacterial growth), $m$ (bacterial growth rate) and $\mathrm{k}$ (curve fitting parameter) were found to be 2.757 (95\% confidence interval from 2.131 to 3.382 ), 0.287 (95\% confidence interval from 0.244 to 0.329 ) and 4.323 (95\% confidence interval from 4.285 to 4.361 ) respectively (Table 3). Von Bertalanffy growth model has been used to mimic the growth of a wide range of species, including fishes, mammals, birds, invertebrates, and microbes. It is a variant of Richards' model, and it is based on biological principles devised by Pütter. For many species, growth rate has been found to correlate with various life-history features, including as fertility and lifespan, making it a crucial driver of organism fitness. The model was first intended to model fish growth in ecology, but it is currently used to model other organisms, including bacterial biodegradation [43-49].

\section{CONCLUSION}

It could be concluded that, based on statistical tests such as corrected AICc (Akaike Information Criterion), bias factor (BF), adjusted coefficient of determination (R2), and root-mean-square error (RMSE), the Von Bertalanffy model was found to be the best model in modelling the growth of Bacillus cereus on malachite green dye. Lower asymptote bacterial growth (A), bacterial growth rate $(\mu)$, and curve fitting parameter, $(\mathrm{k})$ were among the parameters obtained from the fitting exercise. The employment of bacterial growth models to achieve a precise growth rate is beneficial for secondary model development, and this work has proved the capabilities of such models.

\section{REFERENCES}

1. Srivastava S, Sinha R, Roy D. Toxicological effects of malachite green. Aquat Toxicol. 2004;66(3):319-29.

2. Hameed BH, El-Khaiary MI. Equilibrium, kinetics and mechanism of malachite green adsorption on activated carbon prepared from bamboo by $\mathrm{K}_{2} \mathrm{CO}_{3}$ activation and subsequent gasification with $\mathrm{CO}_{2}$. J Hazard Mater. 2008 Sep 15;157(2):344-51.

3. Witek-Krowiak A. Analysis of influence of process conditions on kinetics of malachite green biosorption onto beech sawdust. Chem Eng J. 2011 Jul 15;171(3):976-85.

4. Evangelin Femila EM, Srimathi R, Charumathi D. Removal of Malachite Green using silver nanoparticles via adsorption and catalytic degradation. Int J Pharm Pharm Sci. 2014;6(8):579-83.

5. Kanhere J, Gopinathan R, Banerjee J. Cytotoxicity and genotoxicity of malachite green on non-target aquatic organisms: Chlorella pyrenoidosa and daphnia magna. Water Air Soil Pollut. 2014;225(9).

6. Andersen WC, Casey CR, Nickel TJ, Young SL, Turnipseed SB. Dye residue analysis in raw and processed aquaculture products: Matrix extension of AOAC international official methodsm 2012.25. J AOAC Int. 2018;101(6):1927-39.

7. Jindal R, Sinha R. Malachite Green Induced Ultrastructural Corneal Lesions in Cyprinus carpio and Its Amelioration Using Emblica officinalis. Bull Environ Contam Toxicol. 2019;102(3):377-84.

8. Tkaczyk A, Mitrowska K, Posyniak A. Synthetic organic dyes as contaminants of the aquatic environment and their implications for ecosystems: A review. Sci Total Environ. 2020;717.

9. Kubota R, Lyu X, Minami T. Suppression of Malachite GreenInduced Toxicity to Human Liver Cells Utilizing Host-Guest Chemistry of Cucurbit[7]uril. Anal Sci. 2021;37(3):525-8.

10. Gopinathan R, Kanhere J, Banerjee J. Effect of malachite green toxicity on non target soil organisms. Chemosphere. 2015;120:63744.

11. Mossa A-TH, Mohafrash SMM, Shalaby AR. Toxicity assessment of chlorpyrifos, malachite green and tetracyclines by microtox $₫$ assay: Detoxification by ultrasonic. J Environ Sci Technol. 2017;10(2):6879.

12. Kumbhakar DV, Datta AK, Das D, Ghosh B, Pramanik A, Gupta S Assessment of cytotoxicity and cellular apoptosis induced by azodyes (methyl orange and malachite green) and heavy metals (cadmium and lead) using nigella sativa L. (Black Cumin). Cytologia (Tokyo). 2018;83(3):331-6.

13. Abdel-Fattah Mostafa A, Abdulrahman Al-Askar A, Dawoud TM, Ameen F, Taha Yassin M. In vitro evaluation of antifungal activity of some agricultural fungicides against two saprolegnoid fungi infecting cultured fish. J King Saud Univ - Sci. 2020;32(7):3091-6.

14. Sinha R, Jindal R. Elucidation of malachite green induced behavioural, biochemical, and histo-architectural defects in Cyprinus carpio, as piscine model. Environ Sustain Indic. 2020;8

15. Biswas P, Hasan W, Jain J, Kori RK, Bose D, Yadav RS. Nonpermitted food colorants induced neurotoxicity in cerebellum of rat brain. Drug Chem Toxicol. 2021;

16. Rashtbari S, Dehghan G. Biodegradation of malachite green by a novel laccase-mimicking multicopper BSA-Cu complex: Performance optimization, intermediates identification and artificial neural network modeling. J Hazard Mater. 2021;406.

17. Adenan NH, Lim YY, Ting ASY. Identification and optimization of triphenylmethane dyes removal by Streptomyces $\mathrm{sp}$. from forest soil. Sustain Environ Res. 2021;31(1) 
18. Ji J, Kulshreshtha S, Kakade A, Majeed S, Li X, Liu P. Bioaugmentation of membrane bioreactor with Aeromonas hydrophila LZ-MG14 for enhanced malachite green and hexavalent chromium removal in textile wastewater. Int Biodeterior Biodegrad. 2020;150.

19. Adenan NH, Lim YY, Ting ASY. Discovering Decolorization Potential of Triphenylmethane Dyes by Actinobacteria from Soil. Water Air Soil Pollut. 2020;231(12).

20. Shang N, Ding M, Dai M, Si H, Li S, Zhao G. Biodegradation of malachite green by an endophytic bacterium Klebsiella aerogenes S27 involving a novel oxidoreductase. Appl Microbiol Biotechnol. 2019;103(5):2141-53

21. Tao Y, Wang F, Meng L, Guo Y, Han M, Li J, et al. Biological Decolorization and Degradation of Malachite Green by Pseudomonas sp. YB2: Process Optimization and Biodegradation Pathway. Curr Microbiol. 2017;74(10):1210-5.

22. Sandhiya R, Begum KS, Charumathi D. Decolourization of triphenylmethane dyes and dye industry effluent by Staphylococcus aureus isolated from dye contaminated site. Int J Pharm Pharm Sci. 2016;8(9):258-66.

23. Mnif I, Fendri R, Ghribi D. Malachite green bioremoval by a newly isolated strain Citrobacter sedlakii RI11; Enhancement of the treatment by biosurfactant addition. Water Sci Technol. 2015;72(8):1283-93.

24. Fu X-Y, Zhao W, Xiong A-S, Tian Y-S, Zhu B, Peng R-H, et al. Phytoremediation of triphenylmethane dyes by overexpressing a Citrobacter sp. triphenylmethane reductase in transgenic Arabidopsis. Appl Microbiol Biotechnol. 2013;97(4):1799-806.

25. Cheriaa J, Khaireddine M, Rouabhia M, Bakhrouf A. Removal of triphenylmethane dyes by bacterial consortium. Sci World J. $2012 ; 2012$.

26. Du L-N, Wang S, Li G, Wang B, Jia X-M, Zhao Y-H, et al. Biodegradation of malachite green by Pseudomonas sp. strain DY1 under aerobic condition: Characteristics, degradation products, enzyme analysis and phytotoxicity. Ecotoxicology. 2011;20(2):43846.

27. Gomare SS, Parshetti GK, Govindwar SP. Biodegradation of malachite green by Brevibacillus laterosporus MTCC 2298. Water Environ Res. 2009;81(11):2329-36.

28. Deng D, Guo J, Zeng G, Sun G. Decolorization of anthraquinone, triphenylmethane and azo dyes by a new isolated Bacillus cereus strain DC11. Int Biodeterior Biodegrad. 2008;62(3):263-9.

29. Aisami A, Shukor MYA. Predictive Mathematical Modelling of the Total Number of COVID-19 Cases for the Kingdom of Saudi Arabia. J Environ Microbiol Toxicol. 2020 Jul 31;8(1):11-5.

30. Altuntas S, Cinar A, Altuntas V. Modelling of Listeria monocytogenes growth and survival in presence of royal jelly, a promising anti-biofilm agent. J Food Nutr Res. 2020 Jan;59(1):7-15.

31. Augustin JC, Carlier V, Rozier J. Mathematical modelling of the heat resistance of Listeria monocytogenes. J Appl Microbiol. 1998;84(2):185-91.

32. Baranyi J, Roberts TA. Mathematics of predictive food microbiology. Int J Food Microbiol. 1995 Jul 1;26(2):199-218.

33. Zwietering MH, De Wit JC, Notermans S. Application-of predictive microbiology to estimate the number of Bacillus cereus in pasteurised milk at the point of consumption. Int J Food Microbiol. 1996;30(1-2):55-70.

34. Zwietering MH, De Wit JC, Cuppers HGAM, Van't Riet K Modeling of bacterial growth with shifts in temperature. Appl Environ Microbiol. 1994;60(1):204-13.

35. Baranyi J. Comparison of stochastic and deterministic concepts of bacterial lag. J Theor Biol. 1998;192(3):403-8.

36. Baranyi J. Mathematics of predictive food microbiology. Int J Food Microbiol. 1995;26(2):199-218.

37. Wanyonyi W, Onyari J, Shiundu P, Mulaa F. Enzymatic decolorization of malachite green dye by a newly isolated Bacillus cereus strain wwcp. IOSR J Environ Sci Toxicol Food Technol. 2014 Jan 1;8:58-64.

38. Rohatgi A. WebPlotDigitizer. Austin, Texas, USA; 2017.

39. Uba G, Zandam ND, Mansur A, Shukor MY. Outlier and Normality Testing of the Residuals for the Morgan-Mercer-Flodin (MMF) Model Used for Modelling the Total Number of COVID-19 Cases for Brazil. Bioremediation Sci Technol Res. 2021 Jul 31;9(1):13-9.
40. Umar AM, Shukor MYA. Predictive Mathematical Modelling of the Total Number of COVID-19 Cases for Indonesia. J Environ Microbiol Toxicol. 2020 Aug 1;8(1):27-31.

41. Manogaran M, Yasid NA, Othman AR, Gunasekaran B, Halmi MIE, Shukor MYA. Biodecolourisation of Reactive Red 120 as a Sole Carbon Source by a Bacterial Consortium-Toxicity Assessment and Statistical Optimisation. Int J Environ Res Public Health. 2021 Jan;18(5):2424.

42. Rahman MF, Ahmad SA, MacCormack WP, Ruberto L, Shukor MY Modelling the Effect of Copper on the Mo-reduction Rate of the Antarctic Bacterium Pseudomonas sp. strain DRY1. J Environ Microbiol Toxicol. 2017 Jul 31;5(1):21-5.

43. Edwards MP, Anderssen RS. Symmetries and solutions of the nonautonomous von Bertalanffy equation. Commun Nonlinear Sci Numer Simul. 2015;22(1-3):1062-7.

44. von Bertalanffy L. heoretische Biologie, Zweiter Band: Stoffwechsel,Wachstum. A FranckeAG Verlag, Bern, Switzerland; $1951.418 \mathrm{p}$.

45. Pauly D. The relationship between gill surface area and growth performance in fish: a generalization of von Bertalanffy's theory of growth. Meeresforschung. 1981;28:251-82.

46. Darmani Kuhi H, Kebreab E, Lopez S, France J. A derivation and evaluation of the von Bertalanffy equation for describing growth in broilers over time. J Anim Feed Sci. 2002;11(1):109-25.

47. López S, Prieto M, Dijkstra J, Dhanoa MS, France J. Statistical evaluation of mathematical models for microbial growth. Int J Food Microbiol. 2004;96(3):289-300.

48. Hernandez-Llamas A, Ratkowsky DA. Growth of fishes, crustaceans and molluscs: estimation of the von Bertalanffy, Logistic, Gompertz and Richards curves and a new growth model. Mar Ecol Prog Ser. 2004 Nov 16;282:237-44.

49. Anderson MJ, Millar RB, Blom WM, Diebel CE. Nonlinear multivariate models of successional change in community structure using the von Bertalanffy curve. Oecologia. 2005;146(2):279-86. 